\title{
Historein
}

Vol 13 (2013)

Questions and Orientations in History during the last 20 years. Part 2

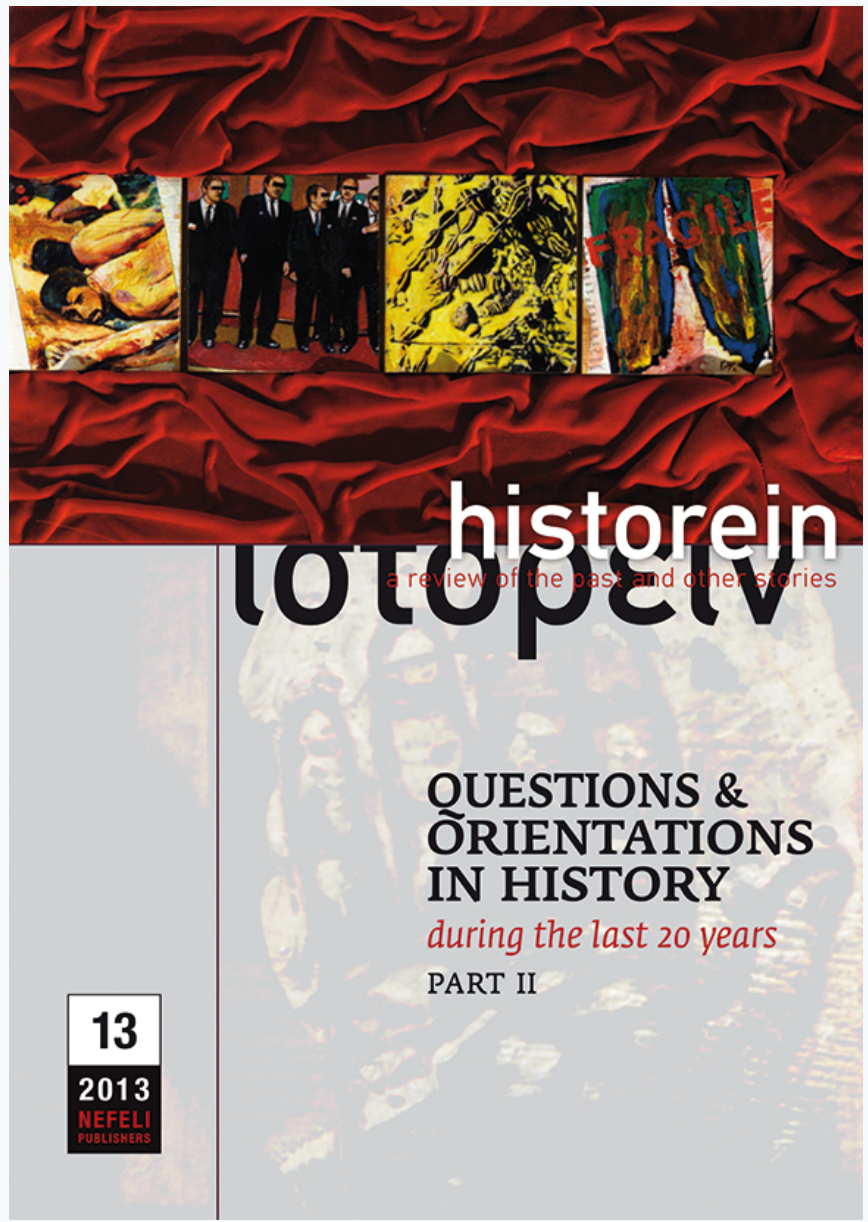

\section{Review of Choman Hardi's Gendered Experiences of Genocide: Anfal Survivors in Kurdistan-Iraq}

Eirini Avramopoulou

doi: $10.12681 /$ historein.243

\section{Copyright @ 2014, Eirini Avramopoulou}

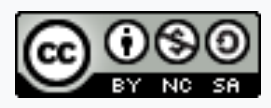

This work is licensed under a Creative Commons Attribution-NonCommercialShareAlike 4.0.

To cite this article:

Avramopoulou, E. (2013). Review of Choman Hardi's Gendered Experiences of Genocide: Anfal Survivors in KurdistanIraq. Historein, 13, 94-98. https://doi.org/10.12681/historein.243 
errors are among the very few features of a book for which the author bears no responsibility. Quite obviously, the need to reduce costs led to the decision that the text should not be edited by a professional proofreader. As a result, the reader's attention is constantly distracted by typographical oversights. I hope that in the book's second edition, which I fervently wish for, the necessary proofreading will not be neglected.

Nevertheless, such omissions do not detract from an otherwise important study that persuasively reorients its field. Its comparative perspective in particular provides a new insight into the formations and transformations of women's initiatives and movements in the Ottoman, Turkish and wider Balkan territories. Kanner's study is a rich book offering fresh knowledge and is open to critique and dialogue, as it constantly raises new questions. In other words, it is an intellectually challenging work.

\section{NOTES}

1 Jack Goody, "Love and religion: comparative comments," in Luisa Passerini, Liliana Ellena and Alexander C.T. Geppert (eds), New Dangerous Liaisons: Discourses on Europe and Love in the Twentieth Century, New York: Berghahn, 2010, 21-32.

2 William M. Reddy, "The rule of love: the history of western romantic love in comparative perspective", in Passerini, Ellena and Geppert (eds), New Dangerous Liaisons, 33-57.

\section{Choman Hardi}

Gendered Experiences of Genocide: Anfal Survivors in Kurdistan-Iraq

\author{
Farnham: Ashgate, 2010. xii + \\ 217 pp.
}

\section{By Eirini Avramopoulou}

University of Cambridge

Conceptualising the situation of Anfal surviving women must involve an appreciation of the dialectic involved in each moment. Survival confronts victimisation. Creation faces up to destruction. Voice talks down to silence. Reconnectivity bridges dislocation. (197)

Choman Hardi's book addresses the aforementioned dialectics, which became part and parcel of what constituted life for women survivors of the "Anfal campaign". The term Al-Anfal, taken from the eighth chapter of the Qur'an, literally means the "spoils of war" (14), as the author denotes in the first chapter. Hardi explains that this term remains mostly unknown in the western world, even though it became associated in 1988 with the horror caused by a military operation launched by Saddam Hussein, which mainly targeted Kurdish and nonMuslim villages in six different geographical areas in northern Iraq. The Anfal operation lasted for six-and-a-half months, from February to September 1988, and entailed mass offensives, aerial bombings, chemical warfare, the destruction of buildings and water resources, and the looting of property; leading to mass deportation, hunger, poverty, illness, psychological and physical trauma as well as vast numbers of deaths and disappearances.

During the eight stages of this operation, people were forced to flee from their villages. If 
not already dying because of the harsh weather conditions, illness and warfare, they were detained by the Iraqi government in prison camps, where most were immediately executed and buried in mass graves. Some of the survivors went into hiding and others sought refuge in the bordering countries of Iran and Turkey, alerting the international community for the first time to their plight. When the operation was over and a general amnesty issued in September 1988, this initiated a new odyssey instead of establishing peace. The survivors returned to their levelled villages and to the realisation that not only had their community vanished, but that under the new regime they had no entitlement to citizenship status, food rations, education or work. The outbreak of the Kurdish civil war intensified this newly precarious status. Even the UN's Food for Oil programme and the Kurdish government's attempts to provide survivors with housing and minimum incomes could not remedy the individual and collective harm that had been done, which had intensified through a lack of political and legal provision for the needs of the survivors. Finally, Anfal was never officially considered as genocide, since the execution of Saddam Hussein in December 2006, before his trial to determine this had concluded, brought the immediate closure of the case (see chapter one). This also reflects other dead ends in the ongoing process of the survivors' need to recover, rebuild their lives, seek justice and closure to their mourning and suffering.

Addressing in detail what happened during and after what became known as the Anfal campaign, which is the aim of this book, is thus not an easy task. It demands that one finds ways to approach difficult questions such as: What does it mean to bear witness to mass violence, trauma, mourning and suffering? How can one listen to, speak and/or write about such events? What does it mean to give voice to such testimonies, especially while employing a gendered prism?

In Hardi's research, the aforementioned questions are not posed as theoretical or philosophical issues. Her elaborate research instead aims to let the reader perceive them mainly in a pragmatic way. Bearing in mind that the Anfal campaign is generally understudied, the author asks: "How can I find the truth in what is based on one person's memory? Does the witness remember correctly? Is she telling the truth? Is she exaggerating? Or should I be asking myself different kinds of questions?" (65). In summary, the author's commitment to searching for the "truth" matches her intention to represent and narrate the stories of women who, in the aftermath of genocide, are injured and traumatised, and, most of all, whose opaque words and worlds have since remained silenced. This silence deserves to find a voice, Hardi notes throughout the book. But how? How can women talk about their experiences especially if they are being advised to keep quiet?

"Najmadeen Faqe Abdullah who was one of the first people to research about Anfal told me that just before being released from the camps, the elders had advised the young that whatever happened in the camps should be abandoned there. This advice was particularly directed at women; don't tell anyone about your own particular suffering or that of another woman, this is for the best" (65). These words depict in a characteristic manner the silence imposed on women. However, not to be able to talk about certain aspects of their experiences should not be perceived as passive. This is one of the main arguments of this book. In the three ethnographically rich chapters following the historical context offered in the first chapter, the author's concern is to voice the particular strategies of survival that these women 
employed in order to fight against their vulnerable status and face the excesses of violence, sexual abuse, hunger, thirst, illness, mistreatment and exploitation. For Hardi, then, silence should also be perceived as a shield against being constantly re-exposed to painful experiences, or as a rational choice for protection in a patriarchal society in which women may be further stigmatised if they remember what really happened (65). In other words, these three chapters variously address the question of what it is that a woman is forced not to remember, or why a woman is prevented from breaking her silence: especially when giving birth in a prison camp equates to witnessing death and that this memory is traumatic (chapter two); when openly discussing sexual abuse and rape might result in honour killings, stigma and the lack of an opportunity to rebuild a decent life (chapter three); when talking about their fears, desperation and hopelessness regarding the conditions of their health after being exposed to gas attacks means that they might be labelled as hysterical (chapter four).

In a context where "survival confronts victimisation" and "voice talks down to silence" (197), Hardi poignantly exposes silence both as a strategy and as an imposition on women, despite what is really uttered or kept quiet. These dialectics are further scrutinised in the final three chapters, which address the painful experience of returning home after violent displacement. This time, silence again looms large, but differently. In the aftermath of war atrocities, "the 'appropriate' remembrance is to talk about what happened during Anfal and not after", Hardi reminds us (181); as, otherwise, this could be more injurious vis-à-vis processes of national and political recuperation. Put differently, when war has annihilated all traces of what could be counted as a liveable and sustainable life, the relics of war - now impersonated in the faces, voices and stories of the genocide's survivors - constitute a greater threat to the consistency, integrity and preservation of the newly established social order. In this sense then, Anfal does not only refer to the "spoils of war" in its literal meaning, but also to denote the spoils of memory. "Women's battle with hunger, filth, menstruation, illness, birth, death, and sexual abuse in the prison camps, the grimness of life in refugee camps and in hiding while internally displaced, and the traumas and illness associated with gas exposure are not given space in the Anfal narrative" (181). Instead, the "Anfal story" is commemorated differently. The circulation of images of the "crying victims", the black-clad weeping women and the "eternally helpless and depressed survivors" (160) create a feeling of "compassion fatigue" (191) among observers and, at the same time, the footage of levelled villages and mass graves broadcasted alongside politicians' speeches, images of Saddam Hussein's end and the Iraqi Special Tribunal (180) do not address the impoverished living conditions to which the victims continue to be exposed even years later. The constant interest of researchers, journalists, NGO workers and politicians in the "Anfal story" ends up mainstreaming horror in the national imaginary, and turns violence into a spectacle that shadows historicity and political analysis. Moreover, it makes women feel abused when they narrate their lives, or else it makes them feel that their "wounds are picked", or "brinman ekoletewe", as they say in the local idiom (177). It is for this reason that in the last chapter, Hardi provides policy recommendations, targeting the failure of the Kurdish government and the international community to respond to the needs of the survivors and concludes: "The yearly Anfal commemorations and popular culture have not managed to create a healthy understanding of Anfal and they have not made the society respect the sur- 
vivors. They have not made the nation think, create, research, and theorise" (185).

Indeed, remembrance and commemoration are neither simple nor neutral, and many authors have taken on the complicated set of debates about what it means to "give voice" and how to approach histories of trauma and memory. Actually, the ethnography of this book could have served as a particularly illuminating case study for the exploration of theoretical issues pertaining to the interrelation between subjectivity, gender and power visà-vis memories, histories and testimonies of war, forced displacement and trauma, and in situations when heightened political injuries are reinforced by the infliction of further personal harm. However, the theoretical grounding of the book appears weak, something that becomes evident in the normative language it uses, which remains unchallenged. Characteristic of this is the author's shallow engagement with theories of psychology, most evidently in chapter six where the psychological consequences of war on women are catalogued in strict categories such as fear and guilt, numbness and flashbacks, traumatic pain, grief, depression and isolation, contaminated memory, embodied distress, anger, and resolution, without sufficient, in-depth analysis of the social production of such emotional states. This is presented alongside a limited review of feminist approaches to trauma. For example, the author addresses the need to politicise the "wound" by not relying so much on individualistic approaches that examine a person's post-traumatic state, but instead concentrating on the importance of social networks and present experience (159). However, she does not explore this argument further, but instead translates it into policy recommendations. Hence, she focuses on the need to give voice to gendered experiences of catastrophe by listening to women's demands as they complain and express their anger against mainstream Anfal representations; against the Kurdistan Regional Government that neither provides them with sufficient financial resources nor finds the lost bodies of their loved ones; and all those who do not help, listen, care: thereby reinforcing justice (183). But, one might ask: is this enough?

It is only in the book's afterword that the erupting effect of language when one has witnessed horror is more evidently exposed. The author's personal reflections regarding her involvement as a researcher on Anfal, her own educational, class and ethnic background, and the psychosomatic effects that this research has had on her are courageously exposed and hence comprise another small piece of Anfal's scattered puzzle. Opening a Pandora's box for her own inner struggles, this self-reflection makes us realise that one's exposure to psychic injury in the aftermath of war needs to find a much more intellectually challenging language in order to be rendered public, while indeed this might also encounter several dead ends. The author writes: "It took me time to realise that while dealing with the wounds of my community I was in fact addressing my own wounds" (201). Women are empowered when seeking help, Hardi seems to conclude throughout the book, while it is only in the afterword that this picture blurs and some poignant problematisations emerge through the author's own selfreflections.

Veena Das has rightly argued that concrete relations "are like shadows of the more abstract questions" and that the politics of perspective negotiated in personal and collective visions is an issue of "establishing the horizon within which we may place the constituent objects of a description in their relation to each other and in relation to the eye with which they are 
seen".' Hardi's book, essential as it appears to be in order to depict the effects and affects of a post-traumatic experience, has a pragmatism that deprives us of a more elaborated understanding of such horizons. Nevertheless, Hardi's work should be widely read because it is an original work providing a platform for further reflection about issues related to the relationship between the researcher and her object of study, the methodology used to approach sensitive matters related to war and conflict, and the need to voice gendered silence. My criticism should be understood mainly as an invitation to think again about how to address the devastating effects of power, even when silence might find a voice, and about how to make sense of current geopolitical conflict zones, both differently and more acutely.

\section{NOTE}

1 Veena Das, Life and Words: Violence and the Descent into the Ordinary, Berkeley: University of California Press, 2007, 4.

\section{Angeliki Spiropoulou}

\section{Virginia Woolf, Modernity and History: Constellations with Walter Benjamin}

\author{
Basingstoke and New York: Palgrave \\ Macmillan, 2010. viii +240 pp.
}

\section{By Jana Funke}

University of Exeter

Angeliki Spiropoulou's Virginia Woolf, Modernity and History: Constellations with Walter Benjamin examines Virginia Woolf's critical engagement with the past and innovative reworking of conventional historiography. Spiropoulou places Woolf's writings in productive dialogue with Walter Benjamin's theorisation of modernity and philosophy of history. In doing so, she offers an original account of Woolf's critical historiography, presents fresh readings of the wide-ranging engagement with the past in Woolf's fiction and develops important broader arguments concerning modernity and history.

As Spiropoulou reminds us, Woolf was fascinated with history from a young age and, in 1905, decided to write "a real historical work" (162). Even though her desire to write a "proper" history book remained unfulfilled, Woolf's essays, short stories and novels offered abundant opportunity for a critical reflection on historiographical practice and imaginative engagement with the past. Spiropoulou's decision to read Woolf with and against Benjamin yields fascinating insights into both writers' negotiation of the relation between past and present and the wider intellectual context they shared. Throughout her study, Spiropoulou remains alive to the differences between Woolf and Benjamin, but also demonstrates forcefully the many parallels between both 